\title{
Choleretic and antispasmodic effects of Lippia integrifolia aqueous extract
}

\author{
Susana Gorzalczany, ${ }^{* 1}$ Valeria Sülsen, ${ }^{2}$ Flavia Redko, ${ }^{2}$ Cristina Vescina,${ }^{3}$ Liliana \\ Muschietti, ${ }^{2}$ Virginia Martino, ${ }^{2}$ Cristina Acevedo ${ }^{1}$
}

${ }^{1}$ Cátedra de Farmacología, Facultad de Farmacia y Bioquímica, Universidad de Buenos Aires, Junín 956 (1113), Buenos Aires, Argentina,

${ }^{2}$ Cátedra de Farmacognosia, Facultad de Farmacia y Bioquímica, Universidad de Buenos Aires, Junín 956 (1113), Buenos Aires, Argentina,

${ }^{3}$ Cátedra de Química Analítica, Facultad de Farmacia y Bioquímica, Universidad de Buenos Aires, Junín 956

\author{
(1113), Buenos Aires, Argentina
}

\begin{abstract}
RESUMO: "Efeitos colerético e antiespasmódico do extrato aquoso de Lippia integrifolia". $\mathrm{O}$ extrato aquoso das partes aéreas de Lippia integrifolia foi ensaiado quanto aos seus efeitos colerético e antiespasmódico. Doses de 250,500 e $750 \mathrm{mg} / \mathrm{kg}$ administradas oralmente em ratos aumentaram significativamente o fluxo biliar e a saída de ácidos biliares. O extrato também exibiu uma significativa redução das contrações induzidas por acetilcolina, $\mathrm{CaCl}_{2}$ e $\mathrm{KCl}$ em jejuno isolado de rato. $\mathrm{O}$ conteúdo total de derivados dos ácidos cafeoilquínicos, expressado como ácido clorogênico foi de $0.10 \% \mathrm{w} / \mathrm{v}$ através de determinação espectrofotométrica.
\end{abstract}

Unitermos: Lippia integrifolia, Verbenaceae, efeito colerético, efeito antiespasmódico.

\begin{abstract}
The aqueous extract of the aerial parts of Lippia integrifolia has been assayed for its choleretic and antispasmodic effects. Doses of 250,500 and $750 \mathrm{mg} / \mathrm{kg}$ administered orally in rats significantly increased the bile flow and the bile acid output. The extract also showed a significant reduction of the contractions induced by acetylcholine, $\mathrm{CaCl}_{2}$ and $\mathrm{KCl}$ on isolated rat jejunum. The total caffeoyl quinic acids derivatives content, expressed as chlorogenic acid was $0.10 \% \mathrm{w} / \mathrm{v}$ by spectrophotometric determination.
\end{abstract}

Keywords: Lippia integrifolia, Verbenaceae, choleretic effect, antispasmodic effect.

\section{INTRODUCTION}

The genus Lippia, from the Verbenaceae family, includes approximately 200 species of herbs, shrubs and small trees mainly distributed in South and Central America and tropical Africa. Traditional uses of 52 medicinal species, belonging to this genus, have been extensively revised (Pascual et al., 2001). Most of them are mainly employed for the treatment of respiratory and gastrointestinal disorders (Agra et al., 2007). Despite this, there are scarce pharmacological reports which could provide scientific validation of their popular uses (Silva et al., 2006; Oliveira et al., 2006; Sena-Filho et al., 2006).

Six of about 31 species of Lippia growing in North and Central Argentina (Zuloaga, 1999), are indicated for gastrointestinal disorders as decoctions: Lippia alba, L. asperifolia, L. fissicalyx, $L$. grisebachiana, L. integrifolia and L. turbinata (Rondina et al., 2003).

Among them, Lippia integrifolia (Gris.) Hieronymus (Verbenaceae) is an aromatic shrub, known popularly as "pulco", "poleo", "incayuyo", "té del inca", "manzanilla", "manzanillo" and "inca yerba", that grows in La Rioja, San Juan, Catamarca, Salta, Jujuy, Tucumán and Córdoba Provinces. The decoctions of leaves and flowers are traditionally used against dyspepsia, indigestions and stomachaches, as diuretic, emmenagogue, antibiotic (for gonorrhoeal infections), febrifuge, for cough treatment and as a sedative (Rondina et al., 2003; Ratera and Ratera, 1980). In rural areas it is used in feet baths. A twig of the plant placed behind the ear is used for headaches affecting one side of the head (Hieronymus, 1882). In Argentina L. integrifolia is an ingredient of some aperitive beverages and teas and also is included in the "Código Alimentario Argentino" (Argentine Food Code). There are only few reports about the chemistry of this species, mainly regarding the composition of its essential oil (Fricke et al., 1999).

Pharmacological reports about L. integrifolia extracts can be found in the literature (Coronel et al., 2003; Leitao et al., 2006; Dellacasa et al., 2003; Muschietti et al., 2005; Sülsen et al., 2006). However, to the best of our knowledge, none of them is related to the treatment of gastrointestinal disorders, the most relevant use of this species in traditional medicine. As a part of 
our ongoing research, the aim of our study therefore was to evaluate the choleretic and antispasmodic effects of L. integrifolia aqueous extract (LIAE) by experimental models in rats.

\section{MATERIAL AND METHODS}

\section{Plant material}

Aerial parts of L. integrifolia (Gris.) Hieronymus (Verbenaceae) were collected in Ampimpa, Tafí del Valle, Tucumán Province, Argentina. The material was identified by Lic. Alberto Slanis and a voucher specimen is deposited at the Herbarium of Fundación Miguel Lillo, under the number 178.

\section{Preparation of the aqueous extract (LIAE)}

The aerial parts of L. integrifolia $(50 \mathrm{~g})$ were air-dried, ground to powder and extracted by maceration with hot water $(500 \mathrm{~mL})$ at room temperature for 20 minutes. The extract was filtered and freeze-dried (yield $19.18 \% \mathrm{w} / \mathrm{w}$ of dried plant material).

\section{Drugs}

Acetylcholine hydrochloride and sodium dehidrocholate were purchased from Sigma Chemical Co (St. Louis, MO, USA). All reagents used were of analytical grade. Dilutions were made fresh on the day of experiment.

\section{Animals}

Female Sprague Dawley rats $(210 \pm 10 \mathrm{~g})$ were obtained from Animal House of the Facultad de Farmacia y Bioquímica, Universidad de Buenos Aires. They were used taking into account international principles and local regulations concerning the care and use of laboratory animals (Olfert et al., 1993). The animals had free access to a standard commercial diet and water $a d$ libitum and were kept in rooms maintained at $22 \pm 1{ }^{\circ} \mathrm{C}$, humidity $60 \pm 5 \%$ and a $12 \mathrm{~h}$ light/dark cycle.

\section{Choleretic activity}

This test was carried out as described by Speroni et al. (2003). Five groups of six rats each were starved for $18 \mathrm{~h}$ before the experiment with free access to water and treated by gastric gavages with LIAE dissolved in water at doses of 250,500 and $750 \mathrm{mg} / \mathrm{kg}(10 \mathrm{~mL} / \mathrm{kg})$ or sodium dehidrocholate (DHC) $500 \mathrm{mg} / \mathrm{kg}(10 \mathrm{~mL} / \mathrm{kg})$ (reference group). Control animals received the same volume of water $(10 \mathrm{~mL} / \mathrm{kg})$. Immediately, animals were anesthetized with urethane (1.2 g/kg; i.p.). Abdomen was opened by a midline incision and the common bile duct was exposed and cannulated just before the hepatic hilus in order to avoid contamination with pancreatic juice. Rectal temperature was monitored and maintained at $37 \pm 0.5{ }^{\circ} \mathrm{C}$ throughout the experiment, using a warming lamp. Bile was collected by gravity in pre-weighted vials at 15 min. intervals. Bile flow (BF) was determined by weight and was expressed as $\mu \mathrm{L} /$ $\mathrm{min} / \mathrm{kg}$ body weight, assuming that the specific gravity of rat bile is 1.0 .

\section{Quantitative determination of bile acids}

Concentration of bile acids was measured in bile samples. The quantitative determination of the major conjugated and free 3-hydroxy bile acids was performed according to Bruusgaard et al. (1970). The micromethod used a NAD-linked 3 hydroxysteroid dehydrogenase reaction with spectophotometric determination of the resultant $\mathrm{NADH}$.

\section{Antispasmodic activity}

Rats were starved for $24 \mathrm{~h}$ before the experiment with free access to water. The animals were killed by cervical dislocation without anesthetic agent in order to avoid any influence on the relaxation responses of the tissue.

Jejunums of approximately $1.00 \mathrm{~cm}$ in length were prepared and placed in $10 \mathrm{~mL}$ organ baths containing Tyrode solution of the following composition (mM): $\mathrm{NaCl} 135, \mathrm{KCl} 5.0, \mathrm{MgCl}_{2}$ 1.0, $\mathrm{NaHCO}_{3}$ 15.0, $\mathrm{NaH}_{2} \mathrm{PO}_{4} 1.0, \mathrm{CaCl}_{2} 2.0$, glucose 11.0. Bath solution was maintained at $31 \pm 1{ }^{\circ} \mathrm{C}$ and constantly oxygenated with $95 \% \mathrm{O}_{2}+5 \% \mathrm{CO}_{2}$. Tissues were connected to a force displacement transducer for the measurement of isometric force. The preparation was allowed to equilibrate for at least $60 \mathrm{~min}$ under $1 \mathrm{~g}$ resting tension, and during this period the incubation media was changed every $15 \mathrm{~min}$. In experiments using high $\mathrm{KCl}$ solution, the equimolar amount of $\mathrm{Na}^{+}$was replaced by $\mathrm{K}^{+}$to maintain constant the ion strength. After equilibration, the following experiments were performed.

\section{Effect on dose-response curves to acetylcholine}

Cumulative dose-response curves for acetylcholine (Ach) $\left(10^{-9}\right.$ to $\left.10^{-5} \mathrm{M}\right)$ were obtained for the tissues. Different concentrations (1.0, 2.0 and 3.0 $\mathrm{mg} / \mathrm{mL}$ ) of LIAE were added to the bath $30 \mathrm{~min}$ before constructing the dose-response curve of the agonist.

\section{Effect on dose-response curves to $\mathrm{CaCl}_{2}$}

After the initial incubation period, the nutrient solution was replaced by calcium-free hyperpotassic medium $\left(\mathrm{K}^{+} 75 \mathrm{mM}\right)$. Cumulative addition of $\mathrm{CaCl}_{2}\left(10^{-4}\right.$ to $\left.3 \times 10^{-2} \mathrm{M}\right)$ in the absence and presence of different concentrations $(0.3,1.0$ and $3.0 \mathrm{mg} / \mathrm{mL})$ of LIAE were 
Table 1. Effect of Lippia integrifolia aqueous extract (LIAE) (250, 500 and $750 \mathrm{mg} / \mathrm{kg}$ p.o.) and DHC (500 mg/kg) on bile flow in rats.

\begin{tabular}{|c|c|c|c|c|c|}
\hline \multirow[t]{2}{*}{$\begin{array}{l}\text { Time } \\
(\mathrm{min})\end{array}$} & \multicolumn{5}{|c|}{ Bile flow $(\mu \mathrm{L} / \mathrm{min} / \mathrm{kg})$} \\
\hline & $\begin{array}{c}\text { Control } \\
\left(\mathrm{H}_{2} \mathrm{O}\right)\end{array}$ & $\begin{array}{c}\text { LIAE } \\
250 \mathrm{mg} / \mathrm{kg} \\
\end{array}$ & $\begin{array}{c}\text { LIAE } \\
500 \mathrm{mg} / \mathrm{kg}\end{array}$ & $\begin{array}{c}\text { LIAE } \\
750 \mathrm{mg} / \mathrm{kg}\end{array}$ & $\begin{array}{c}\text { DHC } \\
500 \mathrm{mg} / \mathrm{kg}\end{array}$ \\
\hline 15 & $67.1 \pm 3.9$ & $76.3 \pm 3.6$ & $107.7 \pm 6.2 * *$ & $98.6 \pm 8.3^{* *}$ & $137.8 \pm 17.3^{* *}$ \\
\hline 30 & $59.6 \pm 2.7$ & $67.4 \pm 2.9$ & $92.9 \pm 4.2 * *$ & $96.2 \pm 9.4 * *$ & $104.6 \pm 14.9^{* *}$ \\
\hline 45 & $58.0 \pm 3.1$ & $63.5 \pm 3.5$ & $85.0 \pm 3.0 *$ & $68.4 \pm 8.2$ & $84.6 \pm 10.5$ \\
\hline 60 & $53.4 \pm 3.8$ & $59.3 \pm 3.5$ & $77.5 \pm 3.3^{*}$ & $64.5 \pm 14.3$ & $74.3 \pm 8.3$ \\
\hline 75 & $49.6 \pm 3.0$ & $56.7 \pm 3.6$ & $75.7 \pm 3.8^{*}$ & $57.2 \pm 16.6$ & $67.1 \pm 8.5$ \\
\hline 90 & $48.9 \pm 2.6$ & $54.4 \pm 3.5$ & $71.9 \pm 4.7 *$ & $56.3 \pm 15.0$ & $62.5 \pm 8.5$ \\
\hline 105 & $46.0 \pm 2.9$ & $56.7 \pm 6.1$ & $74.6 \pm 5.6^{*}$ & $49.6 \pm 15.9$ & $66.0 \pm 9.5$ \\
\hline 120 & $43.8 \pm 1.9$ & $59.7 \pm 6.9$ & $74.4 \pm 6.3^{*}$ & $49.5 \pm 15.0$ & $70.4 \pm 8.3$ \\
\hline
\end{tabular}

Results are expressed as means $\pm \operatorname{SEM}(\mathrm{n}=6),{ }^{*} p<0.05, * * p<0.01$ versus control group (Student-Newman-Keuls test).

used. Each concentration was in contact for $30 \mathrm{~min}$ with the tissue before their effects were evaluated on $\mathrm{CaCl}_{2}$ induced contractions.

\section{Effect on $\mathrm{K}^{+}$induced contractions}

Jejunum was contracted with $\mathrm{KCl}(75 \mathrm{mM})$ which produced a sustained tonic contraction. Different concentrations $(0.3,1.0$ and $2.0 \mathrm{mg} / \mathrm{mL})$ of LIAE were added to the bath. In these experiments, the maximal response to the agonist was regarded as $100 \%$ (control) and the subsequent response in the presence of the extract was calculated as a percentage of the control response.

\section{Statistics}

Pharmacological results are expressed as mean \pm SEM. Differences between control and treated groups were tested for significance using a one-way analysis of variance (ANOVA), followed by Student-NewmanKeuls test or Dunnet test. Differences were considered statistically significant when $p<0.05$ (Graph Pad version 3.1, Graph Soft).

\section{Determination of total caffeoylquinic acids derivatives}

The total caffeoyl quinic acids derivatives content of LIAE was measured spectrophotometrically according to Martino et al. (1989). Chlorogenic acid was used as a calibration standard in the range 5 to 16 $\mu \mathrm{g} / \mathrm{mL}$.

\section{RESULTS}

\section{Choleretic activity}

The effect of orally administered LIAE on rats bile flow is shown in Table 1. Significant increase in $\mathrm{BF}$ was obtained after the first $15 \mathrm{~min}$ from the oral administration of the extract (500 and $750 \mathrm{mg} / \mathrm{kg}$ ). The dose of $500 \mathrm{mg} / \mathrm{kg}$ induced a significant increase $(60.5 \%)$ in $\mathrm{BF}$ beginning at 15 min after administration, which persisted up to the end of the experiment. No significant increase on $\mathrm{BF}$ was observed in animals treated with the dose of $250 \mathrm{mg} / \mathrm{kg}$ of LIAE when compared with the control group. At $500 \mathrm{mg} / \mathrm{kg}$ the reference drug, $\mathrm{DHC}$, induced a marked but transient increase of BF with $105.3 \%$ as a maximum enlargement. Control group presented a slight and regular decrease in BF level during the whole experiment.

\section{Quantitative determination of bile acids}

Total bile acids were determined. The oral administration of LIAE induced a significant increase of bile acids output ( $500 \mathrm{mg} / \mathrm{kg}: 2655.1 \pm 335.2 \mathrm{nmoles} /$

Table 2. $\mathrm{EC}_{50}$ and maximum effect values obtained from the cumulative dose-response curves to $\mathrm{Ach}$ and $\mathrm{CaCl}_{2}$ of Lippia integrifolia aqueous extract (LIAE).

\begin{tabular}{|c|c|c|c|c|c|}
\hline & \multicolumn{2}{|c|}{ Ach } & & \multicolumn{2}{|c|}{$\mathrm{CaCl}_{2}$} \\
\hline & $\mathrm{EC}_{50}(\mu \mathrm{M})$ & $\mathrm{E}_{\max } \pm \mathrm{SEM}$ & & $\mathrm{EC}_{50}(\mathrm{mM})$ & $\mathrm{E}_{\max } \pm \mathrm{SEM}$ \\
\hline Control & $0.0125 \pm 0.004$ & 100 & Control & $1.04 \pm 0.20$ & 100 \\
\hline LIAE & $0.2372 \pm 0.1610 *$ & $60.66 \pm 1.93^{* *}$ & LIAE & $0.89 \pm 0.14$ & $54.52 \pm 6.97 * *$ \\
\hline $1 \mathrm{mg} / \mathrm{mL}$ & & & $0.3 \mathrm{mg} / \mathrm{mL}$ & & \\
\hline LIAE & $0.0459 \pm 0.0129$ & $67.61 \pm 6.74 * *$ & LIAE & $0.86 \pm 0.01$ & $32.15 \pm 8.5^{* *}$ \\
\hline $2 \mathrm{mg} / \mathrm{mL}$ & & & $1 \mathrm{mg} / \mathrm{mL}$ & & \\
\hline $\begin{array}{l}\mathrm{LIAE} \\
3 \mathrm{mg} / \mathrm{mL}\end{array}$ & $0.1418 \pm 0.0846$ & $30.47 \pm 3.93 * *$ & $\begin{array}{l}\mathrm{LIAE} \\
3 \mathrm{mg} / \mathrm{mL}\end{array}$ & $1.2 \pm 0.12$ & $10.31 \pm 2.80^{* *}$ \\
\hline
\end{tabular}

$* p<0.05, * * p<0.01$ versus control curve (Dunnet test). 


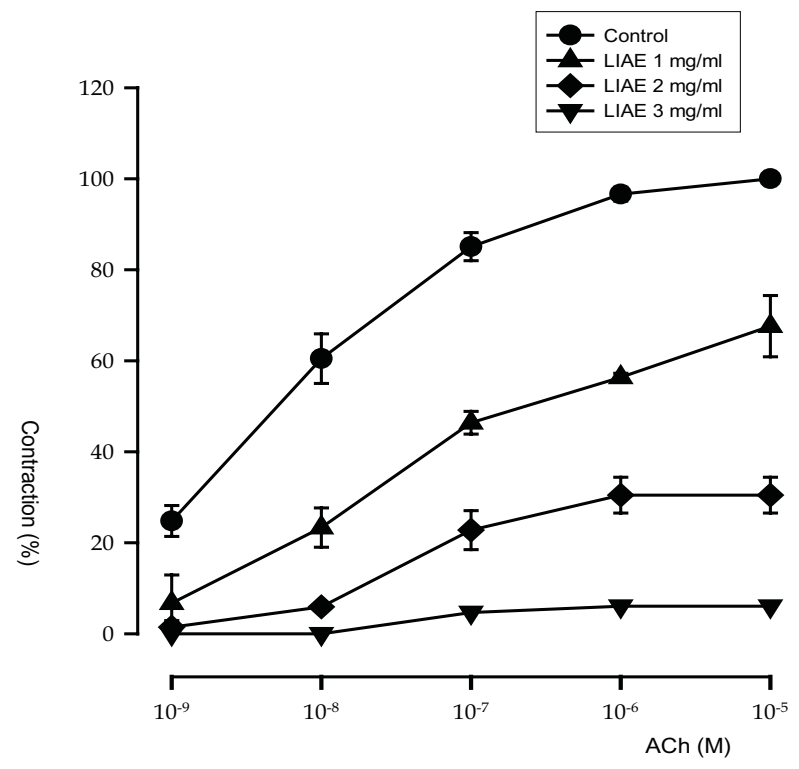

Figure 1. Cumulative log concentration-response curves for Ach in the presence and absence of Lippia integrifolia aqueous extract (LIAE). Contractions are expressed as percentages of the maximum control responses. Each point represents the mean $\pm \operatorname{SEM}(n=5)$.

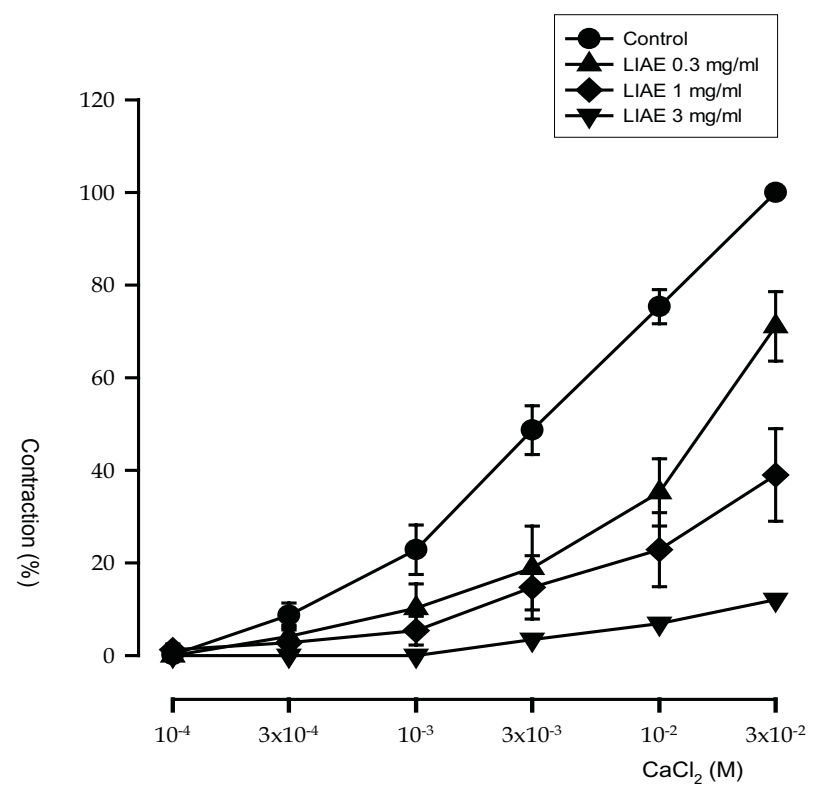

Figure 2. Cumulative log concentration-response curves for $\mathrm{CaCl}_{2}$ in the presence and absence of Lippia integrifolia aqueous extract (LIAE). Contractions are expressed as percentages of the maximum control responses. Each point represents the mean \pm $\operatorname{SEM}(n=5)$.

$\mathrm{min} / \mathrm{kg}$ and $750 \mathrm{mg} / \mathrm{kg}: 2838.8 \pm 241.4 \mathrm{nmoles} / \mathrm{min} / \mathrm{kg}$ ) when compared to the control group (1693.2 \pm 194.9 $\mathrm{nmoles} / \mathrm{min} / \mathrm{kg}$ ).

\section{Antispasmodic activity}

LIAE antagonized muscle contractions induced by $\operatorname{Ach}\left(1 \times 10^{-9}-1 \times 10^{-5} \mathrm{M}\right)$ and $\mathrm{CaCl}_{2}\left(1 \times 10^{-4}-3 \times 10^{-1}\right.$
M) on rat isolated jejunum (Figures 1 and 2). The extract promoted a dose-dependant flattering of concentrationmaximal response curve with Ach and $\mathrm{CaCl}_{2}$ (Table 2). Besides, jejunum contractions induced by $75 \mathrm{mM} \mathrm{KCl}$ were also inhibited in a concentration dependant manner by LIAE $(0.3 \mathrm{mg} / \mathrm{mL}: 31.19 \% \pm 4.17,1 \mathrm{mg} / \mathrm{mL}: 69.63 \%$ $\pm 6.17,2 \mathrm{mg} / \mathrm{mL}: 98.21 \% \pm 1.78)$.

\section{Determination of total caffeoylquinic acids derivatives}

The total caffeoylquinic acid derivatives content in LIAE expressed as chlorogenic acid was $0.10 \% \mathrm{w} / \mathrm{v}$.

\section{DISCUSSION}

A survey of the available literature shows that Lippia species are mostly used for the treatment of gastrointestinal and respiratory disorders. However, there are few reports about the pharmacological activities of these species. Most of them have focused their attention on the antimicrobial, antifungal, giardicidal or larvicidal effects (Pascual et al., 2001; Amaral et al., 2006). In this context, we have studied the choleretic and antispasmodic effects of $L$. integrifolia, an Argentine medicinal species, traditionally used for the treatment of digestive complaints, among other uses. Taking into account that decoctions or infusions of the aerial parts of this plant are used in folk medicine, the aqueous extract of L. integrifolia was assayed.

The results obtained have clearly shown that LIAE exerts a significant choleretic activity with a significant increase of bile flow and of the bile acids out put. Taking into account that bile secretion is mainly induced through two different mechanisms defined as bile acid-dependent and bile acid-independent secretion, the results of the present study suggest that the bile secretion enhancement of LIAE is bile acid-dependent as shown by the significant increase of bile acids output compared to the control group. These pharmacological effects could be due to the presence of mono and dicaffeoylquinic acids since extensive evidences have reported choleretic and hepatoprotective activities for these compounds (Speroni et al., 2003). Choleretic activity of many medicinal plants has been related to the presence of caffeoyl ester derivates (Handa et al., 1986).

In addition, LIAE showed a significant reduction of the contractions induced by acetylcholine, $\mathrm{CaCl}_{2}$ and $\mathrm{KCl}$ on isolated rat jejunum. Gastrointestinal smooth muscle contractions are dependent on intracellular $\mathrm{Ca}^{2+}$ concentration, in this sense, two types of excitation-contraction coupling, based on the type of mechanism responsible for changes in $\mathrm{Ca}^{2+}$, are known. High concentration of extracellular $\mathrm{KCl}$ induces cell depolarisation and consequently activation of voltagedependent calcium channels and $\mathrm{Ca}^{2+}$ influx into smooth 
muscle cell (Al-Zuhair et al., 1996). On the other hand, acetylcholine produces contractions of non-vascular smooth muscle and this effect is mediated by activation of muscarinic receptors causing the release of intracellular calcium stores, without necessarily affecting membrane potential. The results obtained in this study, suggest that the ability of LIAE to attenuate the spasmogenic action of acetylcholine and $\mathrm{KCl}$ is unrelated to a specific receptor antagonism. The dose-dependent shifting of the calcium dose -response curve to the right could indicate a possible calcium channel blockade by the extract. LIAE could act on one or several sites in the final common pathway, inhibiting the calcium influx into the cell cytoplasm or interfering with one of the biochemical processes associated with its influx into the smooth muscle cells. Since we deal directly with the total extract, there may be more than one spasmolytic compound involved or the compounds present in the extract may act through different pharmacological mechanisms.

In conclusion, the results obtained suggest that LIAE exerts a significant choleretic activity, with a bile flow enhancement dependent of bile acids excretion and an antispasmodic effect probably produced by inhibition of calcium influx. Further studies must be conducted in the future, for a better understanding of the involucrated mechanisms and the identification of the active compounds responsible for the pharmacological observed effects.

\section{ACKNOWLEDGMENTS}

The authors wish to thank SECYT-UBA for financial supporting of this study.

\section{REFERENCES}

Agra MF, França PF, Barbosa-Filho JM 2007. Synopsis of the plants known as medicinal and poisonous in Northeast of Brazil. Braz J Pharmacogn 17: 114-140.

Al-Zuhair H, El-Sayeh B, Ameen HA, Al-Shoora H 1996. Pharmacological studies of cardamom oil in animals. Pharmacol Res 34: 79-82.

Amaral FMM, Ribeiro MNS, Barbosa-Filho JM, Reis AS, Nascimento FRF, Macedo RO 2006. Plants and chemical constituents with giardicidal activity. Braz J Pharmacogn 16(Supl.): 696-720.

Bruusgaard A 1970. Quantitative determination of the major 3-hydroxy bile acids in biological material after thinlayer chromatographic separation. Clin Chim Acta 28: 495-504.

Coronel A, Vega M, Lampasona M, Catalán C 2003. Antibacterial activity of two Lippia species. Biocell 27: 111.

Dellacasa A, Bailac P, Ponzi M 2003. In vitro activity of essential oils from San Luis - Argentina against Ascosphaera apis. J Essent Oil Res 15: 282-285.

Fricke C, Hardt I, König W, Joulain D, Zygadlo J, Guzman C 1999. Sesquiterpenes from Lippia integrifolia essential oil. J Nat Prod 62: 694-696.

Handa SS, Sharma A, Chakraborti KI 1986. Natural products and plants as liver protecting drugs. Fitoterapia 57: 307-351.

Hieronymus J 1882. Contribuciones a la materia médica Argentina. Boletín de la Academia de Ciencias en Córdoba (Argentina) 4: 406.

Leitao S, Castro O, Fonseca E, Juliao L, Tavares E, Leo R, Vieira R, Oliveira D, Leitao G, Martino V, Sülsen V, Barbosa Y, Pinheiro D, da Silva P, Teixeira D, Junior I, Lourenço M 2006. Screening of Central and South American plant extracts for antimycobacterial activity by the Alamar Blue test. Braz J Pharmacogn 16: 6-11.

Martino V, Ferraro G, Debenedetti S, Coussio J 1989. Determinación espectrofotométrica del contenido de acidos cafeoilquínicos en especies Argentinas de compuestas usadas en medicina popular. Acta Farm Bonaerense 8: 3-9.

Muschietti L, Derita M, Sülsen V, Muñoz J, Ferraro G, Zacchino S, Martino V 2005. In vitro antifungal assay of traditional Argentine medicinal plants. $J$ Ethnopharmacol 102: 233-238.

Olfert E, Cross B, McWilliam A 1993. Canadian Council of Animal Care: Guide to the care and use of experimental animals Vol.1, $2^{\text {nd }}$ edn.

Oliveira FP, Lima EO, Siqueira Júnior JP, Souza EL, Santos BHC, Barreto HM 2006. Effectiveness of Lippia sidoides Cham. (Verbenaceae) essential oil in inhibiting the growth of Staphylococcus aureus strains isolated from clinical material. $\mathrm{Braz} J$ Pharmacogn 16: 510-516.

Pascual M, Slowing K, Carretero E, Sánchez Mata D, Villar A 2001. Lippia: traditional uses, chemistry and pharmacology: a review. J Ethnopharmacol 76: 201-214.

Ratera E, Ratera M 1980. Plantas de la Flora Argentina Empleadas en Medicina Popular. Hemisferio Sur: Buenos Aires, 121.

Rondina R, Bandoni A, Coussio J 2003. Plantas Silvestres Argentinas con Reconocidas Propiedades Medicinales o Toxicas. OEA-CYTED: Buenos Aires, CD-ROM.

Sena-Filho JG, Melo JGS, Saraiva AM, Gonçalves AM, Psiottano MNC, Xavier HS 2006. Antimicrobial activity and phytochemical profile from the roots of Lippia alba (Mill.) N.E. Brown. Braz J Pharmacogn 16: 506-509.

Silva MIG, Gondim APS, Nunes IFS, Sousa FCF 2006. Utilização de fitoterápicos nas unidades básicas de atenção à saúde da família no município de Maracanaú (CE). Braz J Pharmacogn 16: 455-462.

Speroni E, Cervellati R, Govoni P, Guizzardi S, Renzulli C, Guerra M 2003. Efficacy of different Cynara scolymus preparations on liver complaints. J Ethnopharmacol 86: 203-211.

Sülsen V, Güida C, Coussio J, Paveto C, Muschietti L, Martino V 2006. In vitro evaluation of trypanocidal activity in plants used in Argentine traditional medicine. Parasitol Res 98: 370-374.

Zuloaga F 1999. Catálogo de las Plantas Vasculares de la República Argentina II. Missouri Botanical Garden Press: St. Louis, 1153-1158. 